\title{
Postero-Lateral Fissure of the Spinal Cord
}

National Cancer Institute

\section{Source}

National Cancer Institute. Postero-Lateral Fissure of the Spinal Cord. NCI Thesaurus.

Code C33389.

A narrow groove on either side of the posterior median fissure of the spinal cord where the posterior nerve roots enter. 